\title{
The Suitability of Word Games for Teaching English Vocabulary Based on Curriculum 2013
}

\author{
Kamal Yusuf ${ }^{1}$, Cici Dwi S. ${ }^{2}$ \\ ${ }^{1}$ Faculty of Adab and Humanities, UIN Sunan Ampel Surabaya, Indonesia \\ ${ }^{2}$ Faculty of Education, UIN Sunan Ampel Surabaya, Indonesia \\ ${ }^{1}$ kamalinev@gmail.com, ${ }^{2}$ cici_ds@gmail.com
}

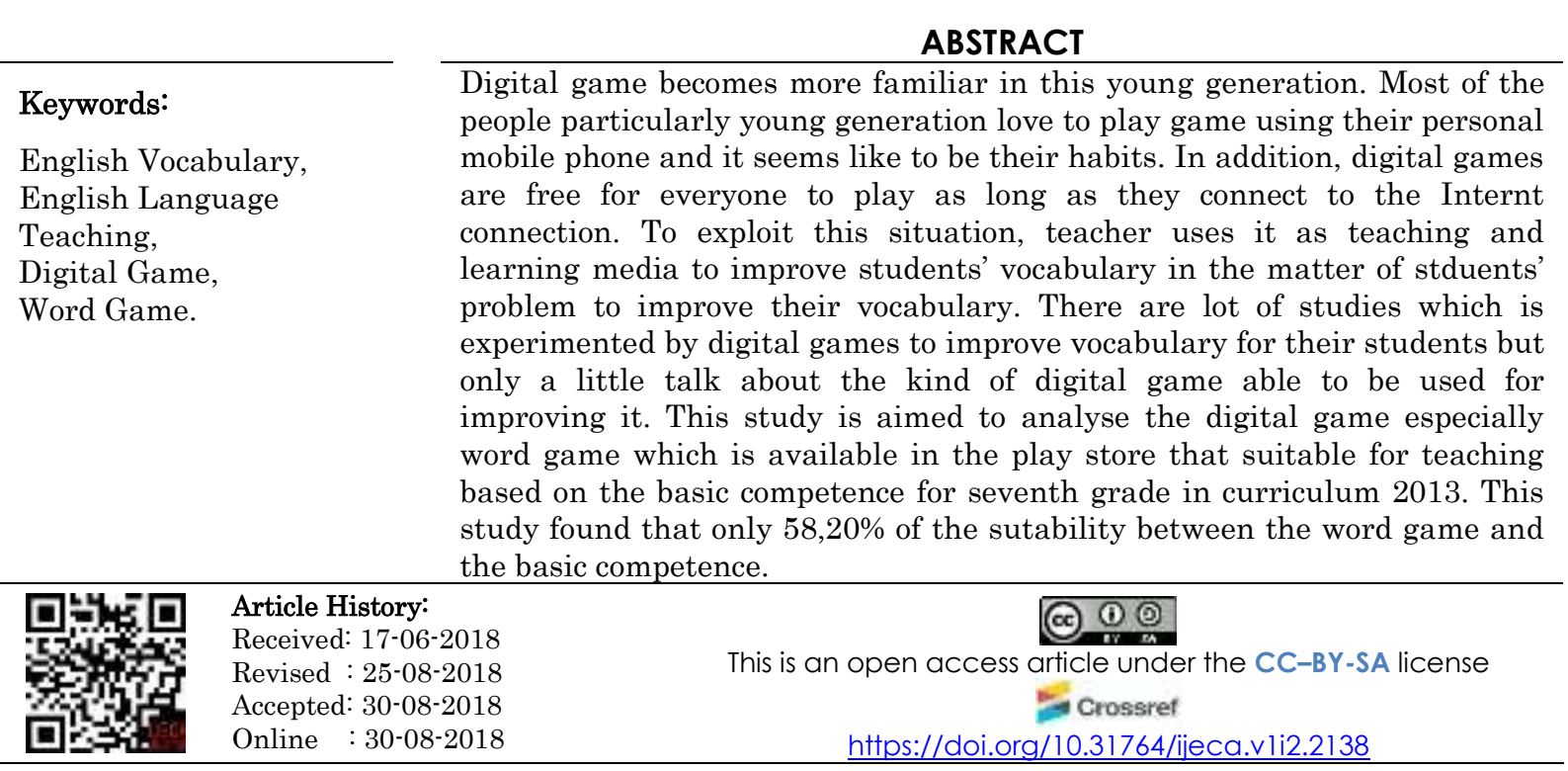

\section{A. INTRODUCTION}

Vocabulary is widely considered to be an important part in English. As stated by Wilkins in Thornbury (Thornbury \& Scott, 2012), without grammar only a little can be conveyed, without vocabulary nothing can be conveyed. It means, vocabulary grips the important role of learning English. The last a decade there are many studies investigate the way to improve vocabulary among the EFL and L2 Learners in easy and fun game. Lots of media used to improve learners' vocabulary one, of the media is digital games. Digital games used as media pertinent with the students' interest against mobile phone. A study by Anderson investigated the use of digital games to improve students' vocabulary and the result was that the study shows students feel they can learn English through a course that uses computer games. Moreover, Shahriarpoura \& Kafi (Shahriarpour \& kafi, 2014) in her study asserts that digital games do increase motivation of learners toward learning, and as a consequent, changing the direction from rote learning to meaningful learning.

The utilizing of digital games is one of the factors which make the learners interested and motivated. As the additional study by Yip (Yip \& Kwan, 2006) got the finding that experimental group outperformed the control group statistically in the post-test. The students in the experimental group generally preferred online learning supplemented with digital educational 
games to conventional activity-based lessons. This study took place in university. Another research was done by Aslanabadi (Aslanabadi \& Rasouli, 2013) which take kindergarten in Iran as the place of the research. The study indicated that there are statistically significant differences in mean scores of vocabulary test in favour of the experimental group in the post application.

Although digital games is proven effective to improve the English Learners' vocabulary, those studies is not well grounded. Those studies only investigate whether the games is effective or ineffective for improving students' vocabulary, none from the previous studies investigate what kind of game can be used for teaching English specially about improving students' vocabulary. This study concerned with word games as a helpful digital game media to teach vocabulary with the objectives to investigate which word game is most appropriate in many based competence on basic competence curriculum 2013 for seventh grade of junior high school students in Indonesia.

Since the digital era, most of the students agree that digital game is become part of their live. (Gros, 2007) write the genres of digital game in his research paper. Those kinds of digital game are:

1. Action games (also called platform games) - these games are reaction based; most of the games of the first generation are action games.

2. Adventure games - the player solves a number of tests in order to progress through a virtual world.

3. Fighting games-these games involve fighting against computer-controlled characters or those controlled by other players.

4. Role-playing games-Human players assume the characteristics of some person or creature.

5. Simulations - the player has to succeed within some simplified recreation of a place or situation to achieve a particular goal.

6. Sports games-these games are based on sports.

7. Strategy games-these games that recreate a historical or fictional situation to allow a player to devise an appropriate strategy to achieve a goal.

Digital games have become the new strategy in teaching English. This is in line with Ang \& Zaphiris (Ang \& Zaphiris, 2011) who mentions that computer game based language learning focuses on computer games as a virtual environment that supports language learning on its own and computer games as a tool or medium to facilitate collaborative learning. Digital computer game takes the role of improving students' vocabulary. According to Deubel (Deubel, 2006), digital game-based learning has the ability to engage and motivate students and present learning experiences while helping long-term memory and providing practical experience. In addition, Griffiths (Griffiths, 2010) added, video or digital games supply a great tool for managing educational research. Griffiths asserts that digital games have "great variety," while attracting students of various demographic backgrounds. Using digital games in order to improve students' skill is good choice for the teacher in digital era nowadays; teacher can improve students' vocabulary in easy way.

Aghlara \& Tamjid (Aghlara \& Tamjid, 2011) investigated the effect of using a digital computer game and its role on promoting Iranian children's vocabulary learning. The research was conducted using experimental research with 40 children as the subject of the research. The result indicated that the mean score of the children in the experimental group was significantly higher than those in the control group, indicating the positive effect of using digital games in teaching English vocabulary to children. It means that digital games bring a benefit for teacher 
who teaches grammar with game. This study support the result of Aghlara \& Tamjid (Aghlara \& Tamjid, 2011) research, Jalali \& Dousti (Jalali \& Dousti, 2012) in their research has investigated the effect of computer educational games on Iranian elementary learners' grammar and vocabulary gain. This experimental research take pre and post-test during the research with 58 female EFL learners. The result of the study was computers have a significant role in motivating learners' involvement in the learning process.

\section{B. METHODS}

This research used qualitative design. Qualitative research is aimed to obtain meanings or to understand in depth the indications, incidents, facts or certain problem regarding social phenomenon and humanity with its complexities. Shank (Shank, 2002) stated that qualitative research is a form of systematic empirical inquiry into meaning. Another expert like Bogdan and Biklen (Bogdan, Robet, Biklen, 2007) argued that qualitative research is descriptive which the data is collected in the form of words or pictures rather than numbers. Data in the form of quotes from documents, field notes, and interviews or excerpts from videotapes, audiotapes, or electronic communications are used to present the findings of the study. Based on the statement of the expert this research is suitable use the qualitative design because this research will analyse the digital games which there will be many description in word than number.

In this study the authors uses descriptive method attempt to analyse and interpret the available digital games that can be used to teach vocabulary for the junior high school students. They need many descriptions of each games in order to obtain the way how to use it. In other condition, this study counts the percentage and generates the average of 20 digital games as the research sample. Thus, the authors determines result gap to raise the conclusion of this study.

In this study the data used by the authors is document the data was taken from the Basic curriculum one to eight based on curriculum 2013 the study specify the vocabulary needed in each basic competence. The next data was taken from the play store to collect the word game used to be analysed.

In this study the authors will use content analysis. The authors will analyses the vocabulary need to be learnt by the students based on the basic competence. Next, the authors use the documentation to obtain the data include taking note of available games, writing the description of the game, and writing the command of other player that usually written below the game before we install the game. There are many digital games will be tried by the authors.

The authors also make a checklist to make the authors easier to make the report. The authors will also record the tutorial of using the digital game then the authors will also write the command of the other player to know whether the game is good or bad. The instrument used in this research is table of column. The table content of basic competence and the name of word games used. The tables used to make the authors easier to analyse which game is suitable for teaching vocabulary in each basic competence.

\section{RESULT AND DISCUSSION}

In the context to answer the research question, the Table 1 showed the result that the word games which available in play store mostly suitable for teaching vocabulary based on basic competence in curriculum 2013. There are eight basic competences used to teach English for 
seventh grade junior high school students in Indonesia. The authors selected 20 kinds of word games which actually there are lots of word games but several of them are similar to each other.

Table 1. Digital games used for teaching English vocabulary

\begin{tabular}{|c|c|c|c|c|c|c|c|c|c|c|}
\hline No & $\begin{array}{c}\text { Name of } \\
\text { Game }\end{array}$ & $\begin{array}{l}\mathrm{KD} \\
3.1 \\
\end{array}$ & KD 3.2 & KD 3.3 & KD 3.4 & $\begin{array}{l}\mathrm{KD} \\
3.5 \\
\end{array}$ & KD 3.6 & $\begin{array}{l}\mathrm{KD} \\
3.7 \\
\end{array}$ & KD 3.8 & $\begin{array}{c}\text { Averag } \\
\mathrm{e}\end{array}$ \\
\hline & $\begin{array}{l}\text { cabulary } \\
\text { ded per KD }\end{array}$ & $\begin{array}{l}\text { Greet } \\
\text { ing }\end{array}$ & $\begin{array}{l}\text { SUB. } \\
\text { Pos. } \\
\text { Adj. } \\
\text { Pos. } \\
\text { Pro }\end{array}$ & $\begin{array}{c}\text { Cardin } \\
\text { al } \\
\text { Ordina } \\
1 \\
\text { Numbe } \\
\text { r }\end{array}$ & $\begin{array}{c}\text { Animal } \\
\text { Things } \\
\text { Plural } \\
\text { and } \\
\text { Singula } \\
\text { r }\end{array}$ & Adj. & $\begin{array}{l}\text { Simple } \\
\text { Presen } \\
\text { t Tense }\end{array}$ & $\begin{array}{l}\text { Descr } \\
\text { iptive } \\
\text { Adj. }\end{array}$ & $\begin{array}{c}\text { Comm } \\
\text { on }\end{array}$ & - \\
\hline 1 & $\begin{array}{l}\text { Word } \\
\text { Connect }\end{array}$ & & & & & & & & $\sqrt{ }$ & $12.5 \%$ \\
\hline 2 & $\begin{array}{l}\text { Vocabulary } \\
\text { Test }\end{array}$ & & & & & & & & $\sqrt{ }$ & $12.5 \%$ \\
\hline 3 & $\begin{array}{l}\text { Learn } \\
\text { English } \\
\text { Vocabulary } \\
\text { Words }\end{array}$ & & $\sqrt{ }$ & $\sqrt{ }$ & $\sqrt{ }$ & $\sqrt{ }$ & $\sqrt{ }$ & & $\sqrt{ }$ & $75 \%$ \\
\hline 4 & $\begin{array}{l}\text { Vocabulary } \\
\text { - Simple } \\
\text { Word } \\
\text { Games }\end{array}$ & & & & & & & & $\sqrt{ }$ & $12.5 \%$ \\
\hline 5 & $\begin{array}{l}\text { Power } \\
\text { Word }\end{array}$ & & & & & & & & $\sqrt{ }$ & $12.5 \%$ \\
\hline 6 & Vocalingo & & & & & & & & $\sqrt{ }$ & $12.5 \%$ \\
\hline 7 & $\begin{array}{l}\text { Power } \\
\text { Vocab } \\
\end{array}$ & & & & & & & & $\sqrt{ }$ & $12.5 \%$ \\
\hline 8 & $\begin{array}{l}\text { Magoosh } \\
\text { Vocab } \\
\text { Builder } \\
\end{array}$ & & & & & & & & $\sqrt{ }$ & $12.5 \%$ \\
\hline 9 & $\begin{array}{l}\text { A Word of } \\
\text { Day }\end{array}$ & & & & & & & & $\sqrt{ }$ & $12.5 \%$ \\
\hline 10 & $\begin{array}{l}7 \text { Little } \\
\text { Words }\end{array}$ & & & & & & & & $\sqrt{ }$ & $12.5 \%$ \\
\hline 11 & $\begin{array}{l}\text { Words with } \\
\text { Friends }\end{array}$ & & & & & & & & $\sqrt{ }$ & $12.5 \%$ \\
\hline 12 & $\begin{array}{l}\text { Penny Dell } \\
\text { Cross Word }\end{array}$ & & & & & & & & $\sqrt{ }$ & $12.5 \%$ \\
\hline 13 & $\begin{array}{l}\text { Pink Fonk } \\
\text { Word } \\
\text { Power }\end{array}$ & $\sqrt{ }$ & $\sqrt{ }$ & $\sqrt{ }$ & & $\sqrt{ }$ & & $\sqrt{ }$ & $\sqrt{ }$ & $75 \%$ \\
\hline 14 & Lingo kids & $\sqrt{ }$ & $\sqrt{ }$ & $\sqrt{ }$ & $\sqrt{ }$ & $\sqrt{ }$ & $\sqrt{ }$ & $\sqrt{ }$ & $\sqrt{ }$ & $100 \%$ \\
\hline 15 & $\begin{array}{l}\text { Big English } \\
\text { Word } \\
\text { Games }\end{array}$ & & & $\sqrt{ }$ & $\sqrt{ }$ & & & & $\sqrt{ }$ & $37.5 \%$ \\
\hline 16 & $\begin{array}{l}\text { Word } \\
\text { collect }\end{array}$ & & & & & & & & $\sqrt{ }$ & $\begin{array}{l}12.5 \% \\
\mathrm{~S} \\
\end{array}$ \\
\hline 17 & $\begin{array}{l}\text { Word Wow } \\
\text { Big City }\end{array}$ & & & & & & & & $\sqrt{ }$ & $12.5 \%$ \\
\hline 18 & $\begin{array}{l}\text { Hangman } \\
\text { Word } \\
\text { Games } 2018 \\
\end{array}$ & & & & $\sqrt{ }$ & & & & $\sqrt{ }$ & $12.5 \%$ \\
\hline
\end{tabular}




\begin{tabular}{|c|c|c|c|c|c|c|c|c|c|c|}
\hline No & $\begin{array}{c}\text { Name of } \\
\text { Game }\end{array}$ & $\begin{array}{l}\mathrm{KD} \\
3.1 \\
\end{array}$ & KD 3.2 & KD 3.3 & KD 3.4 & $\begin{array}{l}\mathrm{KD} \\
3.5 \\
\end{array}$ & KD 3.6 & $\begin{array}{l}\mathrm{KD} \\
3.7 \\
\end{array}$ & KD 3.8 & $\begin{array}{c}\text { Averag } \\
\mathrm{e}\end{array}$ \\
\hline \multicolumn{2}{|c|}{$\begin{array}{c}\text { Vocabulary } \\
\text { needed per KD }\end{array}$} & $\begin{array}{c}\text { Greet } \\
\text { ing }\end{array}$ & $\begin{array}{l}\text { SUB. } \\
\text { Pos. } \\
\text { Adj. } \\
\text { Pos. } \\
\text { Pro }\end{array}$ & $\begin{array}{c}\text { Cardin } \\
\text { al } \\
\text { Ordina } \\
1 \\
\text { Numbe } \\
\text { r }\end{array}$ & $\begin{array}{c}\text { Animal } \\
\text { Things } \\
\text { Plural } \\
\text { and } \\
\text { Singula } \\
\mathrm{r}\end{array}$ & Adj. & $\begin{array}{l}\text { Simple } \\
\text { Presen } \\
\text { t Tense }\end{array}$ & $\begin{array}{r}\text { Descr } \\
\text { iptive } \\
\text { Adj. }\end{array}$ & $\begin{array}{c}\text { Comm } \\
\text { on }\end{array}$ & - \\
\hline 19 & $\begin{array}{l}\text { Learn } \\
\text { English } \\
\text { Vocabulary }\end{array}$ & $\sqrt{ }$ & $\sqrt{ }$ & $\sqrt{ }$ & $\sqrt{ }$ & $\sqrt{ }$ & & & $\sqrt{ }$ & $75 \%$ \\
\hline 20 & $\begin{array}{l}\text { Learn } \\
\text { English } \\
\text { Language \& } \\
\text { Vocab } \\
\end{array}$ & & & & $\sqrt{ }$ & & & & $\sqrt{ }$ & $25 \%$ \\
\hline Tota & & 3 & 4 & 5 & 6 & 4 & 1 & 3 & 20 & $\begin{array}{l}58,20 \\
\% \\
\end{array}$ \\
\hline
\end{tabular}

From the analysis, the authors evaluate the average percentage in three points. The word games can be said suitable for teaching if the percentage more than $70 \%$ and approximately suitable if the percentage round about $60 \%$ and weak if the percentage less than $60 \%$. It was found that the average percentage appears 58,20\%. It means that the ability of teacher who teaches students in seventh grade of junior high school is not being able to conduct the games as a teaching media.

From the explanation of the Table 1, the data can be further explained as the follows: Basic competence 1 , the vocabulary needed by the basic competence one is about greeting. Word games that suitable for teaching basic competence one are Pink fonk word power, Lingo Kids, and Learn English Vocabulary.

Basic competence 2 , the vocabulary needed by the basic competence two is about possessive adjective and possessive pronoun. Word games that suitable for this basic competence are Learn English Vocabulary Word, Pink fonk word power, Lingo Kids, and Learn English Vocabulary.

Basic competence 3, the vocabulary needed by the basic competence one is about cardinal ordinal number. Word games that suitable for teaching basic competence three are Learn English Vocabulary Word Pink fonk word power, Lingo Kids, and Learn English Vocabulary.

Basic competence 4 , the vocabulary needed by the basic competence one is about animal, thing, plural and pronoun. Word games that suitable for teaching basic competence four are Lingo Kids, Learn English Vocabulary Word, Big English word game, Hang man word games, 2018, Learn English language and vocab and Learn English Vocabulary.

Basic competence 5, the vocabulary needed by the basic competence one is about Adjective. Word games that suitable for teaching basic competence five are Learn English Vocabulary Word, Pink fonk word power, Lingo Kids, and Learn English Vocabulary.

Basic competence 6 , the vocabulary needed by the basic competence one is about simple present tense. Word games that suitable for teaching basic competence six is only lingo kids. Basic competence 7 , the vocabulary needed by the basic competence seventh is about adjective. Word games that suitable for teaching basic competence one are Pink fonk word power, Lingo Kids, and Learn English Vocabulary word.

Basic competence 8 , the vocabulary needed by the basic competence eight is common because in this basic competence learn about song and there is specific vocabulary for this basic competence. Word games that suitable for teaching basic competence are all the word games. 
The word game is suitable for improving the students' vocabulary it is in line with Deuble (2006) who state that by using digital game students can be more motivatd to improve their vocabulary. Although the result showed that digital game used in this research which is word game is not showing the suitablity between the game and the basc competence, it does not mean word game cannot improve students' vocabulary.

Digital game brings good impact to students' vocabulary but contrast with this steatement (Gros, 2007) state that digital game like video game is not the solution to educational problems because the content of game can produce a simplification and not approriate theme for the students. Several digital game serve bad content and theme, yet, i is the role of the teacher to sort out the game before giving to the students to play. However many teachers and students believe that digital game is good to improve students vocabulary and bring good impact to their English skill.

\section{CONCLUSION AND SUGGESTIONS}

The findings showed that digital game especially word game that available in play store are aproximately suitable for teaching vocabulary based basic competence in curiculum 2013. The word game that can be applied in many basic competence usually are available in purchased game. The purchased game is quite suitable for teaching vocabulary but teacher may also use free game for another activity in improving students' vocabulary.

Although digital game has good impact for students in learning vocabulary, teacher also need to consider the digital game used for teaching to avoid the bad impact for the students knowing that there are lots of digital game is not suitable as the media of teaching. Dempsey (Dempsey et al., 2002) states that the game selection criteria to select the good game for students to study: (1) The game must be relatively simple to play. (2) The game can be adapted and reprogrammed inexpensively. (3) The game must have some identifiable potential for educational use, if adapted. (4) The game must be different from the other games in its category. (5) The game must be designed so that it can be played by a single player. Digital games have proven give good impact for students' vocabulary. From many kinds of digital games, word games were chosen to be analysed in this study.

\section{ACKNOWLEDGEMENT}

This study is an independent research. We would like to thank the International Journal of Education and Curriculum Application for publishing this article.

\section{REFERENCES}

Aghlara, L., \& Tamjid, N. H. (2011). The effect of digital games on Iranian children's vocabulary retention in foreign language acquisition. Procedia - Social and Behavioral Sciences, 29, 552-560. https://doi.org/10.1016/j.sbspro.2011.11.275

Ang, C. S., \& Zaphiris, P. (2011). Computer Games and Language Learning. In Handbook of Research on Instructional Systems and Technology (pp. 449-462). https://doi.org/10.4018/978-1-59904-865$9 . \operatorname{ch} 032$

Aslanabadi, H., \& Rasouli, G. (2013). The effect of games on improvement of Iranian EFL vocabulary knowledge in kindergartens. International Review of Social Sciences and Humanities, 6(1), 186-195.

Bogdan, Robet, Biklen, K. S. (2007). Qualitative research for education : an introduction to theories and methods | Bogdan, Robert; Biklen, Sari Knopp | download. In Alien and Bacon, Inc, New York. https://b-ok.cc/book/2665513/7b28b9

Dempsey, J. V., Haynes, L. L., Lucassen, B. A., \& Casey, M. S. (2002). Forty simple computer games and what 
they could mean to educators. Simulation and Gaming, 33(2), 157-168. https://doi.org/10.1177/1046878102332003

Deubel, P. (2006). Game on! Now Educators Can Translate Their Students' Love of Video Games into the Use of a Valuable, Multifaceted Learning Tool. T H E Journal (Technological Horizons In Education), 33(6), 30.

Griffiths, M. (2010). Online video gaming: What should educational psychologists know? Educational Psychology in Practice, 26(1), 35-40. https://doi.org/10.1080/02667360903522769

Gros, B. (2007). Digital games in education: Me design of games-based learning environments. Journal of

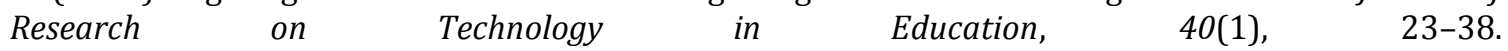
https://doi.org/10.1080/15391523.2007.10782494

Jalali, S., \& Dousti, M. (2012). Vocabulary and grammar gain through computer educational games. GEMA Online Journal of Language Studies, 12(4), 1077-1088.

Shahriarpour, N., \& kafi, Z. (2014). On the Effect of Playing Digital Games on Iranian Intermediate EFL Learners' Motivation toward Learning English Vocabularies. Procedia - Social and Behavioral Sciences, 98, 1738-1743. https://doi.org/10.1016/j.sbspro.2014.03.601

Shank, G. (2002). Being a skilled qualitative researcher. In Qualitative research: A personal skills approach (pp. 3-17).

Thornbury, S., \& Scott, T. (2012). How to Teach Speaking - Scott Thornbury. In Journal of Education and Practice (Vol. 3, Issue 2). https://doi.org/10.1093/eltj/cci025.

Yip, F. W. M., \& Kwan, A. C. M. (2006). Online vocabulary games as a tool for teaching and learning English $\begin{array}{llll}\text { vocabulary. } \quad \text { Educational } & \text { Media }\end{array}$ https://doi.org/10.1080/09523980600641445 